\section{Kanamycin Sensitivity of Mango Somatic Embryos}

\author{
Helena Mathews and Richard E. Litz \\ University of Florida, IFAS, Tropical Research and Education Center \\ Homestead, FL 33031
}

\begin{abstract}
Additional index words. Mangifera indica, embryoid, tissue culture, kanamycin sensitivity
\end{abstract}

\begin{abstract}
Mango (Mangifera indica L.) somatic embryos representing various developmental stages were subjected to various concentrations of kanamycin in the culture medium. The level of kanamycin necessary for growth inhibition was dependent on the size and stage of the somatic embryos at the time of treatment and the kind of exposure. Growth of proembryos in liquid suspension was arrested at $12.5 \mu \mathrm{g} \cdot \mathrm{ml}^{-1}$, while the maturation of later stages of somatic embryos on solid medium was inhibited at 200 $\boldsymbol{\mu} \cdot \mathbf{m l}^{-1}$.
\end{abstract}

Genetic transformation is a potential tool for the improvement of crop plants. Recombinant DNA techniques for introducing foreign genes into plants involve the use of dominant selectable markers that are expressed at the cell and whole-plant levels. The most widely used and tested marker is the gene for neomycin phosphotransferase (NPT II) (EC 2.7.1.95), which confers resistance to the antibiotic kanamycin (Bhatia et al., 1986; Fraley et al., 1986; Schell, 1987).

Mango is a tropical fruit of major economic importance. Somatic embryogenesis from nucellar explants has been demonstrated in both monoembryonic and polyembryonic mango cultivars (Litz, 1984; Litz et al., 1982). As a preliminary step in genetic transformation experiments involving the kanamycin resistance marker gene, we have carried out a detailed investigation to determine the toxic level of the antibiotic on mango somatic embryos at various stages of development. McGranahan et al. (1988) previously demonstrated that walnut embryogenic proembryos can be used as explants for Agrobacterium-mediated transformation.

Embryogenic cultures were initiated from mango nucellus according to procedures described elsewhere (Litz, 1984; Litz et al., 1982, 1984). Suspension cultures of proembryonic masses and cell aggregates were grown in maintenance medium (DeWald et al., 1989a) consisting of B-5 major salts (Gamborg et al., 1968), MS minor salts and organics (Murashige and Skoog, 1962), 6\% (w/v) sucrose, $400 \mathrm{mg}$ glutamine/liter, and $4.5 \mu \mathrm{M} 2,4-\mathrm{D}$.

Growth responses of mango somatic embryos to kanamycin sulfate (Sigma, St. Louis) were tested at four developmental stages. Most experiments were carried out using 'Parris', a polyembryonic cultivar, or 'Tommy Atkins', a monoembryonic cultivar. Initial ex-

Received for publication 24 Mar. 1989. Univ. of Fla. Agr. Expt. Sta. Journal Series no. 9848. The cost of publishing this paper was defrayed in part by the payment of page charges. Under postal regulation, this paper therefore must be hereby marked advertisement solely to indicate this fact. periments indicated that small proembryos were more sensitive to kanamycin than those of later stages of embryogeny. Therefore, the concentration range of kanamycin selected for each experiment was dependent on the size and stage of the somatic embryos at the time of exposure to the antibiotic. Increase in fresh weight was calculated as the ratio of final to initial weight.

Stage 1. Proembryos of 'Parris' at the 840 16-cell stage of development were obtained by passing embryogenic suspensions through $300-\mu \mathrm{M}$ mesh nylon filtration fabric. The fine fraction containing embryos of size $<300 \mu \mathrm{m}$ was retrieved, and $\approx 16 \mathrm{mg}$ of proembryos was inoculated into $50 \mathrm{ml}$ of liquid selection medium in 125-ml Erlenmeyer flasks. Selection medium consisted of the maintenance formulation with filter-sterilized kanamycin sulfate at $\mathrm{O}, 12.5,25$, or $50 \mu \mathrm{g} \cdot \mathrm{ml}^{-1}$. Each treatment consisted of five replicates.

Stage 2. Larger proembryos of 'Parris' than used in stage 1 were obtained from suspensions that had been subculture from maintenance medium into liquid embryogenesis medium, i.e., maintenance medium without 2,4-D (DeWald et al., 1989a), and passed through $1000-\mu \mathrm{m}$ mesh nylon filtration fabric. About $58 \mathrm{mg}$ of the larger proembryos, but $<1000 \mu \mathrm{m}$ across, were inoculated into $50 \mathrm{ml}$ of liquid selection medium in $125-\mathrm{ml}$ Erlenmeyer flasks. Selection medium consisted of the maintenance formulation with filter-sterilized kanamycin sulfate at 0,25 ,

Table 1. Effect of kanamycin on germination and secondary somatic mango embryo formation at Stage 4.,

\begin{tabular}{cccc}
\hline \hline $\begin{array}{l}\text { Kansmycin } \\
\text { concn } \\
\left(\mu \mathrm{g} \cdot \mathrm{ml}^{-1}\right)\end{array}$ & $\begin{array}{c}\text { Germinating } \\
\text { somatic embryos } \\
(\%)\end{array}$ & $\begin{array}{c}\text { Embryos } \\
\text { forming secondary } \\
\text { somatic embryos } \\
(\%)\end{array}$ & $\begin{array}{c}\text { Average fresh wt of } \\
\text { embryos } \pm \mathrm{SE} \\
(\mathrm{g})\end{array}$ \\
\hline 0 & 39.58 & 20.83 & $0.983 \pm 0.101$ \\
20 & 40.00 & 17.5 & $0.861 \pm 0.095$ \\
50 & 20.45 & 4.55 & $0.537 \pm 0.088$ \\
100 & 13.33 & 0.0 & $0.406 \pm 0.059$ \\
200 & 3.64 & 0.0 & $0.204 \pm 0.052$ \\
\hline \hline
\end{tabular}

${ }^{2}$ Culture period 65 days.

${ }^{y}$ Average number of embryos scored per treatment: 120.
50, and $100 \mu \mathrm{g} \cdot \mathrm{ml}^{-1}$. Each treatment consisted of five replicates.

Stage 3. Globular somatic embryos of 'Parris' and 'Tommy Atkins' were collected after passage of the suspensions through 2500 $\mu \mathrm{M}$ mesh nylon filtration fabric. A packed volume of $3 \mathrm{ml}$ of somatic embryos, obtained by centrifugation of the fine fraction (embryo size $<2500 \mu \mathrm{M}$ ) at $100 \times g$ for 5 rein, was plated on solid medium containing B-5 salts, MS organics, 4\% (w/v) sucrose and $20 \%(\mathrm{v} / \mathrm{v})$ filter-sterilized coconut water with filter-sterilized kanamycin sulfate at 0 , 50,100 , or $200 \mu \mathrm{g} \cdot \mathrm{ml}^{-1}$. Each treatment consisted of five replicates per cultivar.

Stage 4. Somatic embryos at the torpedo (20 to $30-\mathrm{mm}$ long) stage of development were obtained following the procedure of DeWald et al. (1989b). These were subculture from embryogenesis medium onto solid maturation medium, i.e., maintenance medium without 2,4-D and with $4 \%$ (w/v) sucrose, and $20 \%$ (v/v) filter-sterilized coconut water. The effect of kanamycin on subsequent development of torpedo-stage mango somatic embryos was determined on medium with filter-sterilized kanamycin sulfate at 0 , $20,50,100$, or $200 \mu \mathrm{g} \cdot \mathrm{ml}^{-1}$. The number of embryos that germinated or formed secondary embryos was scored after 45 days in culture. The experiment was replicated with 10 petri plates per treatment with an average of 12 embryos per plate.

The $\mathrm{pH}$ of the media was adjusted to 5.8 before autoclaving at $121 \mathrm{C}$ and $1.1 \mathrm{~kg} \cdot \mathrm{cm}^{-2}$ for $20 \mathrm{~min}$. Solid medium was gelled with $0.17 \%$ Gelrite. All cultures of proembryos and globular embryos were kept in darkness at $25 \pm 2 \mathrm{C}$, whereas germinating somatic embryos were exposed to a 16-hr photoperiod with a light intensity of $25 \mu \mathrm{mol} \cdot \mathrm{s}^{-1} \cdot \mathrm{m}^{-2}$. Suspension cultures were maintained on a gyratory shaker at $120 \mathrm{rpm}$ and were subculture at 5-day intervals.

The normal (control) increase in fresh weight of proliferating cultures of stage 1 proembryos in maintenance medium was at a ratio of 466:1, whereas complete growth inhibition was observed at $12.5 \mu \mathrm{g} \cdot \mathrm{ml}^{-1}$ or higher concentrations of kanamycin during a culture period of 30 days. Kanamycin at 5 $\mu \mathrm{g} \cdot \mathrm{ml}^{-1}$ did not cause any noticeable reduction in growth rate (data not shown). In embryogenesis medium, development of Stage 2 proembryos into early heart-shaped embryos was initiated after $\approx 42$ days (control), 
while in kanamycin-containing medium, further development of proembryos was inhibited. These cultures became brown. For these, the final to initial weight ratio was 250 for the control and $\approx 1$ for those treated. Kanamycin tolerance was similar for 'Tommy Atkins' and 'Parris' when measured at the most advanced stage of proembryo development $(2500 \mu \mathrm{M})$. Somatic embryo development was completely inhibited by kanamycin at 200 $\mu \mathrm{g} \cdot \mathrm{ml}^{-1}$ in both 'Tommy Atkins' and 'Parris'. In selection media with 50 or $100 \mu \mathrm{g}$ kanamycin/ml only one to two somatic embryos developed normally on each petri plate, whereas an average of more than 100 heartshaped somatic embryos developed on each petri plate in the control. Germination of mature somatic embryos and the proliferation of secondary embryos from their hypocotyls were also reduced in 'kanamycin-containing medium (Table 1). When germinating somatic embryos were transferred to fresh medium with the same concentration of kanamycin and exposed to light, control cultures without kanamycin produced lateral roots and green cotyledons, whereas the media with kanamycin $\left(50 \mu \mathrm{g} \cdot \mathrm{ml}^{-1}\right.$ and higher $)$ inhibited hypocotyl elongation and radicle emergence. Chlorophyll impairment in the cotyledons was observed only at 100 and 200 $\mu \mathrm{g}$ kanamycin/ml, but not at the lower concentrations. At $200 \mu \mathrm{g} \cdot \mathrm{ml}^{-1}$ the somatic embryos became black and necrotie. The average fresh weight of mature somatic embryos was also reduced when they were subculture on kanamycin-containing media.

The sensitivity of mango somatic embryos to kanamycin varied with respect to the stage of development of the somatic embryos at time of exposure to the antibiotic and to the nature of kanamycin exposure. Early Stage 1 proembtyos consist of very few cells that are fully bathed in liquid selection medium. This should prevent the occurrence of "escape cells" in screening experiments. Although $12.5 \mu \mathrm{g}$ kanamycin $/ \mathrm{ml}$ drastically affected growth of the smaller (300- $\mu$ M size) proembryos, embryo maturation and germination still occurred with kanamycin at 20 $\mu \mathrm{g} \cdot \mathrm{ml}^{-1}$ (Table 1$)$. Kanamycin at 100 to 200 $\mu \mathrm{g} \cdot \mathrm{ml}^{-1}$ had a negative effect on maturation of somatic embryos. The toxic level of the antibiotic can vary not only from plant to plant but also in various explants of the same species (Guerche et al., 1987; Mathews, 1988). An understanding of kanamycin toxicity at various stages of development is important in any screening procedure. In transformation experiments involving the kanamycin resistance marker gene, transformed Stage 2 mango somatic embryos $(<1000-\mu \mathrm{M}$ size $)$ might be selected at a relatively low kanamycin concentration $(\leq 25$ $\mu \mathrm{g} \cdot \mathrm{ml}^{-1}$ ) in suspension cultures. Subsequent confirmation of tolerance during the maturation stage of development would require a higher kanamycin concentration.

\section{Literature Cited}

Bhatia, C. R., P. Viegas, A. Bhagwat, H. Ma- thews, and N.K. Notani. 1986. Genetic transformation of plants. Proc. Indian Acad. Sci. (Plant Sci.) 96:79-112.

DeWald, S. G., R.E. Litz, and G.A. Moore. 1989a. Optimizing somatic embryo production in mango.
J. Amer. Soc. Hort. Sci. 114:712-716.

DeWald, S. G., R.E. Litz, and G.A. Moore. 1989b. Maturation and germination of mango somatic embryos. J. Amer. Soc. Hort. Sci. 114:837841.

Fraley, R.T., S.G. Rogers, and R.B. Horsch. 1986. Genetic transformation in higher plants. CRC Crit. Rev. Plant Sci. 4:1-46.

Gamborg, O.L, R.A. Miller, and K. Ojima. 1968. Plant cell cultures: I. Nutrient requirements of suspension cultures of soybean root cells. Expt. Cell Res. 50:150-158.

Guerche, P., M. Cherbonnier, L. Jouanin, C. Toumeur, J. Paszkowski, and G. Pelletier. 1987. Direct gene transfer by electroporation in Brassica napus. Plant Sci. 52:111-116.

Litz, R.E. 1984. In vitro somatic embryogenesis from nucellar callus of monoembryonic mango. HortScience 19:715-717.

Litz, R. E., R.K. Knight, and S. Gazit. 1982. Somatic embryos from cultured ovules of polyembryonic Mangifera indica L. Plant Cell Rpt. 1:264-266.

Litz, R. E., R.J. Knight, and S. Gazit. 1984. In vitro somatic embryogenesis fromMangifera indica $\mathrm{L}$. callus. Sci. Hort. 22:233-240.

Mathews, H. 1988. In vitro responses of Brassica juncea and Vigna radiata to the antibiotic kanamycin. Ann. Bet. 62:671-675.

McGranahan, G. H., C.A. Leslie, S.L. Uratsu, L.A. Martin, and A.M. Dandekar. 1988.Agrobacterium mediated transformation of walnut somatic embryos and regeneration of transgenic plants. Biotechnology 6:800-804.

Murashige, T. and F. Skoog. 1962. A revised medium for rapid growth and bioassays with tobacco tissue culture. Physiol. Plant. 15:473497.

Schell, J. 1987. Transgenic plants as tools to study the molecular organization of plant genes. Science 237:1176-1183. 